\title{
(2) Trade Liberalization and Its Effects on the aße Economic Growth of Bangladesh: An Empirical Analysis
}

\author{
Shapan Chandra Majumder ${ }^{1}$, Md. Masud Rana ${ }^{2 *}$ \\ ${ }^{1} \mathrm{PhD}$ Fellow, School of Economics, Shandong University, Shandong, CHINA; \\ \& Assistant Professor, Department of Economics, Comilla University, BANGLADESH \\ ${ }^{2}$ Lecturer, Department of Business Administration, Z.H. Sikdar University of Science and Technology, Kartikpur, Shariatpur, \\ BANGLADESH
}

*E-mail for correspondence: masudstar88@yahoo.com

Received: Mar 07, 2015;

Accepted: Mar 22, 2016;

Published: Jun 18, 2016

Source of Support: Nil

No Conflict of Interest: Declared

\begin{abstract}
The objective of this paper is to assess the effectiveness of the trade policy on Bangladesh economy between the periods 1990 to 2010. This research analyzes the achievements of the economy regarding the important variables such as growth of GDP, export, import, exchange rate, terms of trade, and foreign reserve after the trade liberalization in 1990s. The study demonstrates that the inward policy of the trade liberalization reduces the import while the forward policy increases the employment, production, and export. Finally, liberalization policy improves overall economic indicators as GDP per capita, FDI, and remittances have been growing up since pre-liberalization. The study shows that both export and import have increased noticeably since liberalization, with import rising faster than export in the period immediately after liberalization.
\end{abstract}

Keywords: Trade Policy, Trade Liberalization, Export, Import, Bangladesh

\section{INTRODUCTION}

Bangladesh is one of the potential economies in the world. The average annual real GDP growth of the Bangladesh economy during the last one decade was over $6 \%$, aided by conductive macroeconomic policies, strong export growth, and favorable weather. GDP growth was broadly based on agriculture, industry, and service sectors performing well (WTO). Bangladesh launched a wide-ranging trade reform strategy in the early 1990s. This included substantial reduction and rationalization of tariffs, removal of quantitative restrictions, move from multiple to a unified exchange rate system, convertible current account and an overall outward orientation of trade policy regime. As a result, the trade integration of the country, measured by the trade-GDP ratio, rose from $18 \%$ in 1990 to $48 \%$ in 2012 (WDI, 2014).

Trade and Commerce is one of the prime driving forces of socio-economic development over the last three decades. The economic and policy orientation of Bangladesh has evolved considerably, from a highly interventionist regime with widespread control on trade, the exchange rate, and investment to a substantially liberalized economic regime. At independence in 1971, Bangladesh faced the daunting challenge of rehabilitating its economy, which had suffered dislocation and devastation during a bloody war. The situation concerning the external sectors was particularly difficult (Rahman, 2013).

From its first year of independence in 1971, Bangladesh followed an import substitution industrialization strategy for a decade. Trade policies were based on high tariffs and quantitative restrictions on imports, resulting in an anti-export bias. The trade liberalization process started in the mid-1980s, with the primary objective to create a neutral trade regime by reducing and ultimately eliminating the anti-export bias. Liberalization of the import regime was accomplished primarily through the removal of import bans and quantitative restrictions. To increase the competitiveness of domestic industries, the customs duty was greatly reduced for raw materials and capital goods used as inputs for manufacturing exports, while it was kept high on final goods. Overall, the customs duty rate was reduced from 350\% in 1991 to 
37.5\% in 2000 (Trade Policy Review, 2000). To increase transparency, the Harmonized System was introduced in July 1988, and the multiple-rate sales tax was replaced by a 15\% value-added tax in 1992 (Trade Policy Review, 1992). Following this, the number of four-digit codes subject to quantitative restrictions was reduced from 550 (26\%) in 1987 to $124(10 \%)$ in 2000 (Munshi, 2008).

The export promotion was also one of the main objectives of Bangladesh trade policy reform. Several measures were undertaken in order to encourage export, including new incentives and facilities for the exporters, duty and taxfree imports of inputs for exporters, creation of the Export Processing Zones, and most importantly, improvement of export policy administration. These reforms helped expand the export base mainly by increasing nontraditional exports; the remarkable success of the readymade garments industry is an example (Bhattacharya et al., 2002).

After reviewing the previous studies, this research foregrounds its rationale and significances in subsequent sections. It is followed by the analyses of the Trade Policy and the Trade Liberalization Policy. Then, after mentioning the research methods it shifts to discuss the results and findings of the study. It furthers by finding out problems or disadvantages of the trade liberalization and by recommending some suggestions based upon these problems and disadvantages. And, finally, it draws the conclusion.

\section{LITERATURE REVIEW}

There are many studies assuming that trade liberalization increases gross domestic product by proper utilization of the domestic resources. Morgan and Kanchanahatakij (2008) assess that trade liberalization is an association of economic growth with increased levels of international trade.

Then, in an influential paper, Krugman (1990) summarizes the reasons why trade liberalization is good for growth in developing countries. Firstly, developing countries have production patterns that are skewed towards labor intensive service, agriculture, and manufacturing. People have low per capita incomes, and markets in such countries are usually small. A liberalized trade regime allows low-cost producers to expand their output well beyond that demanded in the domestic market. Secondly, whereas industrialization based on protection of domestic industries thus results in evenhigher capital intensity of production, the open trade regime permits enjoyment of constant returns to scale over a much wider range and finally import substitution regimes normally give bureaucrats considerable discretion either in determining which industries should be encouraged or in allocating scarce foreign exchange in a regime of quantitative restrictions, leading to serious efficiency losses. Kraay and David Dollar (2001) examine that trade liberalization increases growth and reduce the poverty level in developing country. Alesina and Wacziarg (1998) investigate that trade openness has a strong positive impact on economic growth. Frankel and Romer (1999) using cross-country regressions conclude that trade has a quantitatively large, significant and robust positive effect on income. Georgios (2003) studied fifty-six countries covering the period between 1951 and 1998, and another of one hundred and five countries over 1960 to 1997. The results show that the effect of trade openness on economic growth is positive.

In Bangladesh, there are some studies investigating the relationship between liberalization and economic growth. Manni and Afzal (2012) found that in Bangladesh, greater trade liberalization has had a favorable effect on economic development. Both real export and import have increased with greater openness. Trade liberalization will encourage a shift of resources from the production of import substitutes to the production of export-oriented goods. Nahar and Siriwardana (2009) conducted a study to identify the impact of trade liberalization policy on poverty reduction in Bangladesh. They found that trade liberalization policy reduces overall poverty in the short run in Bangladesh. Ahmed (2001) found positive effects of trade liberalization on growth in Bangladesh. On the other hand, Siddiki (2002) examines the joint effect of trade and financial liberalization on the overall economic growth of Bangladesh with annual data for 1975-95. Siddiki finds positive effects of both types of liberalization. This research assesses the effectiveness of the trade policy, which is both export and import oriented, and also investigates which are the changes of the macroeconomic indicators in pre and post liberalization period.

\section{RATIONALE AND SignificANCE OF THE StUdy}

In the academic and empirical literature the results of trade liberalization are not settled at all and have continued to be a subject of vigorous scrutiny. In Bangladesh, some studies state the positive impact of trade liberalization while some others say the opposite. In order to examine this unsettled relationship between trade liberalization and economic growth of Bangladesh, this study applies an empirical approach. The primary focus of this study is to assess the potential impact of trade liberalization on economic growth in Bangladesh. The study will significantly help the policy makers to understand whether export oriented industries or import substitution industries should be more emphasized for the growth of the economy. Additionally, it will help to know the behavior of the exchange rate and terms of trade in case of international trade. 


\section{Trade Policy}

The policy reform process gained substantial momentum following the restoration of democracy in 1991. The main political parties embraced a liberal economic agenda, which augured well for genuine and sustained political commitment to reform and to liberalize. Since then, wideranging reforms and liberalization measures have been initiated and implemented, which have virtually been transformed into the policy landscape. These measures include tariff reductions, the elimination of a large number of quantitative restrictions (QRs), a flexible exchange rate regime, and the provision of a range of fiscal and financial incentives for export promotion.

\section{Import Policy Order 2012-15}

According to Bangladesh Trade Policy Support Program (2014), the IPO 2012-15 aims to make the import regime compatible with WTO requirements, simplifies the procedure to import capital machinery and raw materials, provides facilities for technological innovation, and allows import of essential commodities on emergency basis. Apart from duty-free imports of capital machinery and spare parts, export-oriented industries (EOIs) have access to the dutydrawback system and special bonded warehouses whereby customs duties and value added taxes paid on imports of inputs used in the manufacture of finished products are refunded or exempted. EOIs are also entitled to import dutyfree samples (within specified limits) related to the manufacture of exportable products. Provided clearance is obtained from the Export Promotion Bureau (EPB).

\section{Export Policy 2012-15}

Export Policy 2012-15 has underscored the need for expanding export, enhancing the productivity of exportoriented industries and facilitating the overall development of the export sector through capacity building of the local export-oriented industries. Five Business Promotion Councils are already in place under the public-private partnership to enhance capacity and awareness of the exporters, and to mitigate the supply constraints paving the way for uninterrupted supply of exports. The scope of these councils will be expanded gradually. It is expected that this Export Policy will play the pioneering role in employment generation and poverty alleviation through increasing growth of our export.

The export policies of Bangladesh are dominated by ready-made garments (RMG), most of which are exported to the US and the EU. Nearly all garment exports are from firms operating in export processing zones or as bonded warehouses. Until June 2005, there was also an arrangement which paid subsidies on domestic fabrics used by garment exporters. Apart from these, there is a standard array of duty neutralization schemes (e.g. duty drawback), export incentives (e.g. preferential export credit), export promotion institutions, and activities of the kind used in many developing countries (The Trade Policy Overview Report for a Summary).

\section{Trade Liberalization Policy}

\section{Trade Policy Reforms}

During the past three decades, Bangladesh carried out extensive trade policy reforms. In particular, the country has been pursuing a liberal trade policy since the beginning of the 1990s, which is consistent with the trends in the global market economy, Uruguay Round Accord and agreement with the World Trade Organization. The government formulated a five-year export policy along with a more liberal five-year import policy in 1997/98 with the objective of attaining a favorable trade balance and gradual improvement in the foreign exchange reserve situation (GOB 2002). Keeping this goal in mind, the government has been pursuing a limited protective policy only in consideration of several important issues like public health, security and religious restrictions. Also, the government has been adopting more liberal import and export policies and programs including reduction and harmonization in tariff rates, and elimination of many quantitative restrictions on imports (GOB 2002).

\section{Tariff Rationalization}

During the 1990s, Bangladesh not only significantly reduced its tariff rates but also rationalized the tariff structure. The country progressively moved towards obtaining the goal of simplicity and transparency of customs tariffs. The top custom duty rate came down to 32.5 percent in FY 2003 from 350 percent in FY 1992. The average (un-weighted) customs duty (CD) decreased from 57 percent in FY 1992 to 16.5 percent in FY 2003. The average protective tax also declined to 22 percent in FY 2003 compared to 61 percent in FY 1992. Bangladesh progressed a lot towards achieving a degree of uniformity and removing some tariff anomalies that existed due to higher tariffs on intermediate products compared to final products (Ahmed and Sattar 2004).

It may be noted that the nominal import protection level of Bangladesh is now the lowest in South Asia and tariff reduction in the country during the early 1990s is ranked as one of the fastest amongst the reforming countries (Mujeri and Khondker, 2002). Both nominal and effective protection rates have also declined over the years due to changes in the tariff structure.

Table 1: Tariff Structure in Bangladesh

\begin{tabular}{|c|c|c|}
\hline Fiscal Year & Maximum Rate (\%) & $\begin{array}{c}\text { Un-weighted } \\
\text { Tariff Rate (\%) }\end{array}$ \\
\hline $1991-92$ & 350.0 & 70.0 \\
\hline $1992-93$ & 300.0 & 47.4 \\
\hline $1993-94$ & 300.0 & 36.0 \\
\hline $1994-95$ & 60.0 & 25.9 \\
\hline $1995-96$ & 50.0 & 22.3 \\
\hline $1996-97$ & 45.0 & 21.5 \\
\hline $1997-98$ & 42.5 & 20.7 \\
\hline $1998-99$ & 40.0 & 20.3 \\
\hline $1999-00$ & 37.5 & 19.5 \\
\hline
\end{tabular}




\begin{tabular}{|c|c|c|}
\hline $2000-01$ & 37.5 & 18.6 \\
\hline $2001-02$ & 37.5 & 17.1 \\
\hline $2002-03$ & 32.5 & 16.5 \\
\hline $2003-04$ & 30 & 15.6 \\
\hline $2004-05$ & 25 & 13.5 \\
\hline $2005-06$ & 25 & 15.5 \\
\hline $2011-12$ & 25 & 14.9 \\
\hline
\end{tabular}

Source: Raihan and Khondker, 2013 and GoB (2014)

Beginning from the late 1980s, the tariff regime has become increasingly liberalized. Between 1991-92 and 2011-12 the un-weighted average rate of tariff fell from 70 percent to 14.9 percent (Table 1). Much of this reduced protection was achieved through the reduction in the maximum rate. Table 1 suggests that in 1991-92, the maximum tariff rate was 350 percent which came down to only 25 percent in 2011-2012. Bangladesh has no tariff quotas, seasonal tariffs and variable import levies (WTO, 2000).

\section{Elimination of Quantitative Restrictions (QRs)}

The first major slashing of QRs took place under the import policy order for 1991-93, which reduced the number of items on the import control list from 325 to 193. During the period 1993-97, the number of restricted items was cut to between 111 and 120. The import policy order 2003-2006 reduced the number, to 63, of which only 23 are for trade reasons (Rahman, 2013).

Table 2: Removal of QRs at the 4-digit HS Classification Level

\begin{tabular}{|c|c|c|c|c|c|}
\hline \multirow{2}{*}{ Year } & \multirow{2}{*}{ Total } & \multicolumn{3}{|c|}{ Restricted for trade reasons } & $\begin{array}{c}\text { Restricted } \\
\text { for non-trade } \\
\text { reasons }\end{array}$ \\
\cline { 4 - 6 } $1985-86$ & 478 & 275 & 138 & 16 & 49 \\
\hline $1986-87$ & 550 & 252 & 151 & 86 & 61 \\
\hline $1987-88$ & 529 & 257 & 133 & 79 & 60 \\
\hline $1988-89$ & 433 & 165 & 89 & 101 & 78 \\
\hline $1989-90$ & 315 & 135 & 66 & 52 & 62 \\
\hline $1990-91$ & 239 & 93 & 47 & 39 & 60 \\
\hline $1991-92$ & 193 & 78 & 34 & 25 & 56 \\
\hline $1992-93$ & 93 & 13 & 12 & 14 & 54 \\
\hline $1993-94$ & 109 & 7 & 19 & 14 & 69 \\
\hline $1994-95$ & 114 & 5 & 6 & 12 & 92 \\
\hline $1995-97$ & 120 & 5 & 6 & 16 & 93 \\
\hline $1997-02$ & 122 & 5 & 6 & 16 & 95 \\
\hline $2003-06$ & 63 & 5 & 8 & 10 & 40 \\
\hline $2012-15$ & 26 & 4 & 6 & 2 & 14 \\
\hline
\end{tabular}

Source: Raihan and Khondker, 2013 and GoB (2014)

The range of products subject to import ban or restriction has been curtailed substantially from as high as 752 in 1985-86 to only 26 in 2012-15. Import restrictions have been imposed on two grounds: either for trade-related reasons (i.e., to provide protection to domestic industries) or for non-trade reasons (e.g., to protect the environment, public health and safety, and security). Therefore, only the trade-related restrictions should be of interest to policy reforms and liberalization. Table 2 shows the evolution of import restrictions in Bangladesh at the HS 4- digit level, where it is found that over the past two decades the number of trade-related banned items has declined from 275 to 4 .

\section{Methods OF The Study \\ Data Collection}

This research uses four equations and indicates five variables- such as Exchange rate (ExR), Economic growth (GDPG), Export earnings (EX), Import earning (IM), and Terms of Trade (TT). We have taken the data for our regression model from 1990 to 2010 . The study is based on the analysis of secondary data obtained from the Bangladesh Bank, Ministry of Finance of Bangladesh, Bangladesh Bureau of Statistics (BBS) and World Development Indicators (WDI).

\section{Model Specification}

For effectiveness of the export and import policy, we consider the following models. We have taken the data of recent two decades of the Economic Growth (GDPG), ExR, TT, LogEX and LogIM from 1990 to 2010. All data collection for the purpose of the study is evaluated, cross checked compared and critically analyzed.

The models employed in the study includes the following

$G D P G=\beta_{\mathrm{O}}+\beta_{\mathrm{I}} E x R+\beta_{2} T T+u_{i} \ldots \ldots \ldots \ldots \ldots$
$\operatorname{Ln}(E X)=\beta_{\mathrm{O}}+\beta_{\mathrm{I}} E x R+\beta_{2} T T+u_{i} \ldots \ldots \ldots \ldots$
$\operatorname{Ln}(I M)=\beta_{\mathrm{O}}+\beta_{\mathrm{I}} E x R+\beta_{2} T T+u_{i} \ldots \ldots \ldots \ldots \ldots .$.
$E X R=\beta_{\mathrm{O}}+\beta_{\mathrm{I}} \operatorname{Ln}(E X)+\beta_{2} \operatorname{Ln}(I M)+u_{i} \ldots \ldots \ldots$.

Where,

GDPG=Economic Growth of Gross Domestic Product (Annual \%), ExR=Exchange Rate (\$ US), TT=Terms of Trade, Ln $(E X)=$ Export Growth with Log (Export is measured in \$ Million US), Ln (IM) = Import Growth with Log (Import is measured in \$ Million US), $u i=$ Stochastic error term, $\beta_{0}$, $\beta_{1}$ and $\beta_{2}=$ Intercept and slope of the coefficients.

\section{Results AND Discussion}

\section{Interpretation of First Equation}

From the regression results, if exchange rate (ExR) is zero, then the GDP growth rate (GDPG) is -8.576782 , meaning that, if there is no exchange rate variable in Bangladesh macroeconomic environment, then, the GDP growth rate will be $-8.576782 \%$. The value of the constant term is statistically significant at 5\% level of significance.

Based on economic theory and experience, it is expected that there will be a positive relationship between GDP growth rate and exchange rate in Bangladesh. The slope of our GDPG equation is 0.125142 which means that a $1 \%$ increase in the rate of exchange will cause GDP growth rate to increase by $0.125142 \%$, which is positive and statistically significant at 1 percent level. The result of the coefficient $\beta_{2}$ means that if TT increases by 1 percent than on an average 
growth rate will increase about $0.082316 \%$ which is statistically significant at 1 percent level.

The coefficient of determination $\left(\mathrm{R}^{2}\right)$ is 0.716373 which is $72 \%$ variations in the growth are jointly explained by the variation in all the explanatory variables ExR and TT. The remaining $28 \%$ could be attributed to the stochastic error term not included in the model. So we can say that the model is good fitted. The values of the DW and $\mathrm{R}^{2}$ are 1.888382 and 0.716373 respectively. The value of the Durbin-Watson is greater than the value of the $\mathrm{R}^{2}$. That is $1.888382>0.716373$. It means that the regression results are sensible, and the model can be accepted.

To ensure the fitness of the model, specification problems associated with serial correlation, normality, and heteroskedasticity are checked with diagnostics tests, including the test for serial correlation (LM test), heteroskedasticity, and normality $(\mathrm{JB}(\mathrm{N}))$. The results are presented in Table 5, equation (1). Pesaran and Pesaran (1977) suggest by using Brown et al. (1975) stability test. This technique is also known as cumulative sum (CUSUM). The CUSUM statistics is updated recursively and plotted against the break points. If the plots of CUSUM statistics stay in the critical bounds of 5 percent level of significance, the null hypothesis of all coefficients is the given regression are stable cannot be rejected.

The analysis of the results in equation (1) is concluded that growth of gross domestic product in Bangladesh is influenced significantly by the exchange rate and terms of trade. However, this is true in the short - run.

As shown from the above tests, the results shown from the ordinary least square (OLS) are a sensible one and have no problem of heteroscedasticity and autocorrelation. We, therefore, accept the results of the model.

Table 4: Results of the Simple Linear Regression

Equations

\begin{tabular}{|c|c|c|c|c|}
\hline \multicolumn{5}{|c|}{ Regression Results of the Models } \\
\hline Regressors & (1) GDPG & (2) $\operatorname{Ln}(\mathrm{EX})$ & (3) $\operatorname{Ln}(\mathrm{IM})$ & (4) EXR \\
\hline EXR & $\begin{array}{l}0.125142^{*} \\
(0.024509)\end{array}$ & $\begin{array}{l}0.348557^{*} \\
(0.047182)\end{array}$ & $\begin{array}{l}0.489856^{*} \\
(0.080248)\end{array}$ & \\
\hline TT & $\begin{array}{l}0.082316^{*} \\
(0.026634)\end{array}$ & $\begin{array}{c}0.051397 \\
(0.051272)\end{array}$ & $\begin{array}{c}0.171438^{* * *} \\
(0.087205)\end{array}$ & \\
\hline $\operatorname{Ln}(\mathrm{EX})$ & & & & $\begin{array}{l}3.290723^{* *} \\
(0.674306)\end{array}$ \\
\hline Ln(IM) & & & & $\begin{array}{l}-0.189481 \\
(0.568800)\end{array}$ \\
\hline Intercept & $\begin{array}{l}-8.576782^{* *} \\
(3.600487)\end{array}$ & $\begin{array}{l}-11.58374 \\
(6.931161)\end{array}$ & $\begin{array}{c}-22.72031^{* * * *} \\
(11.78877)\end{array}$ & $\begin{array}{l}18.77166^{* *} \\
(3.850646)\end{array}$ \\
\hline $\mathrm{R}^{2}$ & 0.716373 & 0.941531 & 0.879647 & 0.938476 \\
\hline $\begin{array}{c}\text { Durbin- } \\
\text { Watson Stat }\end{array}$ & 1.888382 & 1.283064 & 1.673354 & 1.088868 \\
\hline $\begin{array}{l}\text { Prob.(F- } \\
\text { Statistic) }\end{array}$ & 0.000022 & 0.000000 & 0.000000 & 0.000000 \\
\hline $\begin{array}{l}\text { Standard er } \\
\text { the estimate } \\
\text { statistically } \\
\text { significance }\end{array}$ & $\begin{array}{l}\text { gnificant a } \\
\text { evel. }\end{array}$ & he ${ }^{*} 1 \%$, * & $\begin{array}{l}\text { heses belor } \\
\text { coefficients } \\
\text { o and }{ }^{* * * 10 \%}\end{array}$ & \\
\hline
\end{tabular}

Source: Author's Envies output
Table 5: Diagnostic tests for Equations

\begin{tabular}{|l|c|c|c|c|}
\hline \multicolumn{6}{|c|}{ Diagnostic Tests for the Models LM (х2) } \\
\hline Test Statistics & $(1)$ & $(2)$ & $(3)$ & $(4)$ \\
\hline Serial Correlation & 0.0666 & 0.2011 & 0.3191 & 0.1123 \\
\hline Normality & 0.898046 & 0.816005 & 0.3112 & 0.613411 \\
\hline Heteroskedasticity & 0.7633 & 0.0636 & 0.086305 & 0.6413 \\
\hline $\begin{array}{l}\text { Stability Tests } \\
\text { (CUSUM) }\end{array}$ & Stable & Stable & Stable & Stable \\
\hline
\end{tabular}

Source: Author's Envies output

\section{Interpretation of Second Equation}

In our regression results, where intercept term $\left(\beta_{0}\right)$ is 11.57374, slope coefficient $\left(\beta_{1}\right)$ is 0.348557 and slope coefficient $\left(\beta_{2}\right)$ is 0.051397 . The regression result of intercept term $\left(\beta_{0}\right)-11.57374$ suggests that when the level of the exchange rate and terms of trade are zero, the total export growth is -11.57374 . It indicates a negative relationship between the constant parameter and export. The value of the constant term is statistically insignificant because its $P$-value is more than $5 \%$.

In the log linear model, the slope coefficient of $\beta_{1}$ suggests that a one-unit change in $\operatorname{EXR}(\Delta \mathrm{EXR}=1)$ is associated with a $100 * \beta_{1} \%(100 * 0.348557 \%=34.8557 \%)$ change in EX, that means on average export growth will increase $34.8557 \%$, which is positive relationship and statistically significant at 1 percent level because its $P$ value is lower than 1 percent, almost zero. The result $\beta_{2}$ means that a one-unit change in TT is associated with a $100 * \beta_{2} \%(100 * 0.051397 \%=5.1397 \%)$ change in EX, that means on average export growth will increase by $5.1397 \%$, which is also a positive relationship but statistically insignificant because it's $P$ value is more than 10 percent.

The coefficient of determination $\left(\mathrm{R}^{2}\right)$ is 0.941531 means that $94 \%$ variations in the export growth are jointly explained by the variation in all the explanatory variables EXR and TT.

The values of the DW and $\mathrm{R}^{2}$ are 1.283064 and 0.941531 respectively. The value of the Durbin-Watson is greater than the value of the $\mathrm{R}^{2}$. It means that the regression results are sensible, and the model can be accepted.

To ensure the fitness of the model, specification problems associated with serial correlation, normality and heteroskedasticity are checked with diagnostics tests, including the test for serial correlation (LM test) is 0.2011 , heteroskedasticity is 0.0636 , and normality (JB (N)) is 0.816005 . That means the model has no problem of heteroscedasticity and autocorrelation. And it is also suggested that the model is normally distributed. We, therefore, accept the results of the model. The stability test of the model is checked by the CUSUM statistics and it shows that the regression equation is stable because the 
CUSUM statistics stay in the critical bounds of 5 percent level of significance.

\section{Interpretation of third equation}

The results of the regression indicate that two coefficients are significant at $10 \%$ level of significance. The regression results, where intercept term $\left(\beta_{0}\right)$ is -22.72031 , slope coefficient, $\beta_{1}$ is 0.489856 and slope coefficient $\beta_{2}$ is 0.171438 . The regression result of intercept term, $\beta_{0}$ is 22.72031, suggests that when the level of the exchange rate and Terms of trade are zero, the total import growth is -22.72031 . This indicates a negative relationship between the constant parameter and import. The intercept of the regression line is statistically significant because the probability value is less than 10 percent. The slope coefficient $\beta_{1}$ suggests that a one-unit change in EXR $(\Delta \mathrm{EXR}=1)$ is associated with a $100 * \beta_{1} \%(100 *$ $0.489856 \%=48.9856 \%$ ) change in IM, that means on average import growth will increase $48.9856 \%$, which is positive relationship and statistically significant at 1 percent level, its $P$-value is almost zero. The result $\beta_{2}$ means that a one-unit change in TT is associated with a $17.1438 \%$ change in IM, that means on average import growth will increase by $17.1438 \%$, which is also positive relationship and statistically significant at 10 percent level.

The coefficient of determination $\left(\mathrm{R}^{2}\right)$ is .0 .879647 means that $88 \%$ variations in the import growth are jointly explained by the variation in all the explanatory variables ExR and TT that means the regression line is the best fitted. The joint probability of $F$-statistics in the regression model is also significant because the $P$-value is almost zero. The model is widely accepted because it has no serial correlation, no heteroscedasticity and also normally distributed which is shown in Table 5, Equation (3), and the model is stable by checking CUSUM statistics.

\section{Interpretation of fourth Equation}

In our regression results, where intercept term $\left(\beta_{0}\right)$ is 18.772, slope coefficient $\left(\beta_{1}\right)$ is 3.29 and slope coefficient $\left(\beta_{2}\right)$ is -0189 . The regression result of intercept term $\left(\beta_{0}\right)$ is 18.772 suggests that when growth of export and import are zero, the exchange rate is $18.772 \mathrm{Tk}$. This indicates a positive relationship between the constant parameter and Exchange Rate.

According to equation (4) in Table 5, a 1\% increase in EX is associated with an increase EXR of $0.01 * 3.290723=$ 0.03290723 point, which is statistically significant and a $1 \%$ decrease in IM is associated with an increase exchange rate of $0.01 * 0.189481=0.00189481$ point that means import is negatively insignificant because its P-value is more than 10 percent. Secondly, on the basis of the $F$ statistics, we can conclude that collectively of all explanatory variables are highly statistically significant. The $R^{2}$ value of 0.94 is also very high that means the regression line is the best fitted to the model. The stability of the regression model is checked by various diagnostic tests. The results are reported in Table 5, equation (4) which confirms that the model has the aspiration econometric properties: it has a correct functional form and the model's residuals are serially uncorrelated, normally distributed and homoskedastic. Hence, the results reported are valid for reliable interpretation. Finally, the stability of model is also checked by applying CUSUM techniques and it also shows that the model is stable.

\section{MAIN FINDINGS}

\section{Effectiveness of Export and Import policy}

In our regression analysis, we have observed that there are positive relationships among the variables of economic growth, EXR, and TT which are statistically highly significant. The slope coefficient $\beta_{1}$ in equation (1) suggests that if ExR increases to 1 percent than on average growth will increase by $0.125142 \%$, which is positive relationship and statistically significant at 1 percent level. So, here we see that if the government takes the policy of the currency devaluation for the export-oriented country, it will be more effective for the economic growth.

The slope coefficient of $\beta_{1}$ in equation (2) suggests that, a one-unit change in EXR is associated with a $34.8557 \%$ change in EX, that means on average export growth will increase $34.8557 \%$, which is positive relationship and statistically significant at 1 percent level because its $P$ value is lower than 1 percent, almost zero. The result $\beta_{2}$ means that a one-unit change in TT is associated with a $5.1397 \%$ change in EX. It means on an average, export growth will increase by $5.1397 \%$, which is also a positive relationship but statistically insignificant because $P$-value is more than $10 \%$.

The slope coefficient $\beta_{1}$ in equation (3) suggests that a one-unit change in EXR is associated with a $48.9856 \%$ change in IM, that means on average import growth will increase $48.9856 \%$, which is positive relationship and statistically significant at 1 percent level, its $P$-value is almost zero. The result $\beta_{2}$ means that a one-unit change in TT is associated with a $17.1438 \%$ change in IM, that means on average import growth will increase by 17.1438 $\%$, which is also positive relationship and statistically significant at 10 percent level.

According to equation (4) in Table 5, the slope coefficient of export growth shows that there is a positive relationship between the exchange rates and export growth, a $1 \%$ increase in export (EX) is associated with an increase exchange rate (EXR) of 0.03290723 point, which is 
statistically significant because $p$ value is very low, near zero and a $1 \%$ decrease in import (IM) is associated with an increase exchange rate of 0.00189481 point that means import is negatively insignificant because its P-value is more than 10 percent.

\section{Effectiveness of Trade Liberalization policy}

Trade liberalization policies pursued by Bangladesh have passed through three phases. The first phase (1982-86) was undertaken as Bangladesh came under the purview of the policy based lending of the World Bank; the second phase (1987-91) began with the initiation of the three year IMF structural adjustment facility (SAF) in 1986; and finally, the third phase since 1992, was preceded by the IMF sponsored Enhanced Structural Adjustment Facility (ESAF) (BIDS, 2003). These reform measures led to a significant decline in quantitative restrictions, opening up of trade in many restricted items, rationalization and diminution of import tariffs, and liberalization of foreign exchange regime. This effect is shown in the following table.

Table 6: Changes in Economic Indicators for Liberalization

\begin{tabular}{|l|l|l|l|l|l|l|l|}
\hline \multirow{2}{*}{$\begin{array}{l}\text { Economic Indicators } \\
\text { In million US\$) }\end{array}$} & \multicolumn{2}{l}{ Pre-Liberalization Period } & \multicolumn{3}{l}{ Post-Liberalization Period } \\
\cline { 2 - 9 } & $1976-80$ & $1981-85$ & $1986-90$ & $1991-95$ & $1996-00$ & $2001-05$ & $2006-10$ \\
\hline GDP per capita & 154.2 & 196.8 & 230 & 271.8 & 324 & 354.6 & 504 \\
\hline GDP at constant price & 19164 & 22789 & 27321 & 33472 & 42515 & 55054 & 71837 \\
\hline GDP Growth Rate (\%) & 4.4 & 4 & 4 & 4.4 & 5.2 & 5.2 & 6.2 \\
\hline Total population & 85.6 & 97.8 & 110.8 & 123.2 & 135.8 & 148.2 & 160 \\
\hline Investment & 1747 & 3040 & 4264 & 5686 & 9155 & 13615 & 20089 \\
\hline Inflation (\% chan in CPI) & $\ldots$. & 11.57 & 7.84 & 5.6 & 5 & 5.4 & 7.7 \\
\hline Trade \% of GDP & 18.4 & 16.4 & 18.4 & 22.6 & 31.4 & 36 & 45.2 \\
\hline Total Export & 941.4 & 1381 & 1721 & 2914 & 5460 & 8410 & 15018 \\
\hline Total Import & 2119 & 3321 & 3845 & 4783 & 8166 & 10383 & 17435 \\
\hline Remittances & 144.6 & 510 & 725 & 1008 & 1645 & 3199 & 8481 \\
\hline Current Account Balance & -411.8 & -499 & -526.6 & -3.8 & -396.4 & -23.8 & 1319 \\
\hline FDI inflow & 4.2 & 1 & 2.5 & 6 & 161 & 332 & 623 \\
\hline Real Exchange Rate & $\ldots .$. & 45 & 48 & 48 & 53 & 54 & 63 \\
\hline Real Interest Rate & 6.4 & 1 & 7 & 10.4 & 10 & 11 & 8.2 \\
\hline
\end{tabular}

Source: WDI, 2010 and Manni and Afzal (2012)

The economic indicators in Table 12 clearly show GDP per capita has been increasing since pre-liberalization period and continuing to move at a faster rate up to now. In 2014-15 fiscal years the per capita income in Bangladesh is \$1314 US (BBS). Sustained growth has contributed to a faster reduction in poverty from 48.9 percent in 2000 to 24.5 percent in 2014 implying an average annual rate of decline of 4.3 percent over the period.

Openness in Bangladesh, as measured by the ratio of export plus import-to-GDP, increased from $16 \%$ on average in the ' 80 s to over 48 percent in the 2012s (WDI, 2014). Overall, by aligning nominal exchange rate to reasonably competitive levels and avoiding significant periods of real exchange rate appreciation, Bangladesh was able to preserve export competitiveness substantially.

\section{The Problems or Disadvantages and RECOMMENDATIONS}

This section covers the problems or disadvantages and recommendations of trade liberalization. As the value of the currency of Bangladesh gets devalued, the exportoriented industries immensely rise. However, as these industries are not heavy industries, the export earnings remain less than import expenses. Although the currencies are devalued, the import does not decrease as we could not establish the import substitution industry in the country. So, a great amount of foreign exchange reserve is used to meet the import expenses. Although the trade liberalization has contributed to increase our economic growth a lot, it cannot surpass the volume of import expenses. So the economy of Bangladesh faces trade deficiency.

The analyzing of the empirical findings, the paper provides the following recommendations:

- If the government takes the policy for the currency devolution for export-oriented country, it will be more effective for the economic growth because our research have found that if exchange rate increase to 1 percent, on an average the growth will increase by $0.125142 \%$ which is statistically significant.

- Devaluation is not effective to reduce import until the country could establish import substitution industry. Rather than devaluating currency, as the study suggests, Bangladesh should establish import substitution industry. For this reason our research finds that when the exchange rate increases, the import rate simultaneously increases. It finds that if exchange rate increases to 1 percent, on average 
import growth will increase by $48.9856 \%$ which is also statistically significant.

- The study recommends that growth of export will be increased if a term of trade increases. Our research have found that if terms of trade increase by 1 percent, export growth will increase by $5.1397 \%$ on an average which is also statistically significant.

- It also suggests that growth of import will be decreased when exchange rate rises more because our study have found that if growth of import decreases by 1 percent, exchange rate will increase by $0.00189481 \%$ on an average. It means that import decreases when exchange rate increases more.

- Finally we conclude that in order to enjoy the facilities of trade liberalization, the government of Bangladesh should create fair business environment to attract foreign direct investment and to encourage the local private investors.

\section{CONCLUSION}

Finally, we conclude that export oriented policy increases the growth of the export which restores the balance of payments, and import substitution industry also reduces the imports which help to create the balance of payments. The empirical analysis undertaken in this study suggests that greater liberalization has a favorable effect on economic growth of Bangladesh. Both real exports and imports have increased with greater liberalization. Liberalization policy certainly improves export of the country which eventually leads higher economic growth after the 1990s. Hence, with the empirical evidence and policy suggestions the study tries to reveal the overall effect of trade liberalization on economic growth of Bangladesh.

\section{REFERENCES}

Ahmed, N. (2001). Trade Liberalization in Bangladesh: An Investigation into Trends, the University Press Limited, Dhaka.

Ahmed, S and Sattar, Z. (2004). Trade Liberalization, Growth and Poverty Reduction: The Case of Bangladesh, Washington, D.C., World Bank.

Alesina, A. and Wacziarg, R. (1998). Openness, Country Size and Government. Journal of Public Economics, 69(3), 305-321.

Bangladesh country report (2013). Trade and employment / International Labour Organization, ILO Country Office for Bangladesh. - Dhaka: ILO.

Bangladesh Institute of Development Studies (BIDS) and Federation of Bangladesh Chambers of Commerce and Industry (FBCCI). (2003). The Recent performance of the Bangladesh Economy: An assessment of the state of the economy and short-term outlook. (Seminar Paper). Dhaka.

Bangladesh Trade Policy Support Program (2014), Comprehensive Trade Policy in Bangladesh, Trade Policy Support Programme (TPSP) Project Task Force - HAK Tower (2nd floor) 3/C-1 Karwan Bazar, Dhaka 1215, Bangladesh
Bhattacharya, D., Rahman, M., \& Raihan, A. (2002). The Contribution of the RMG Sector to the Bangladesh Economy, Paper 50, Centre for Policy Dialogue, Dhaka, October.

Dollar, D., \& Kraay, A. (2001). Trade, growth, and poverty. World Bank, Development Research Group. Washington, D.C.

Export Policy 2009-12, Government of the People's Republic of Bangladesh, Ministry of Commerce Bangladesh Secretariat Dhaka.

Export Policy 2012-15, Government of the People's Republic of Bangladesh, Ministry of Commerce Bangladesh Secretariat Dhaka.

Frankel, J. A., \& Romer, D. (1999). Does trade cause growth? The American Economic Review, 89(3), 379 - 399.

Georgios, K. (2003). Trade Openness and Economic Growth, can we Estimate the Precise Effects? Applied Econometrics and International Development. AEEADE Vol.3.

Hossain, M.A., (2008). The Impact of Foreign Direct Investment on Bangladesh's Balance of Payments: Some Policy Implications. Dhaka, Bangladesh: Policy Note 0805, Bangladesh Bank.

IPO (2012). Import Policy Order 2012-2015, Ministry of Commerce, Government of Bangladesh

Krugman, P.R. (1990). Rethinking International Trade. Massachusetts: The MIT Press

Manni, U. H. and Afzalet, M.N.I. (2012), Effect of the trade liberalization on economic growth of developing countries: A case of Bangladesh. Journal of Business, Economics $\mathcal{E}$ Finance, 1(2), 37-44.

Morgan, C.W and. Kanchanahatakij, S. (2008). Trade Liberalization and Economic Growth. The World Economy, 31(6), 701-719.

Mujeri, M., and Khondker, B. (2002). Poverty Implications of Trade Liberalization in Bangladesh: A General Equilibrium Approach. A Project Paper on the Globalization and Poverty Programme funded by the DFID, UK.

Munshi, F. (2008). Does openness reduce wage inequality in developing countries? A Panel data Analysis. School of Business, Economics and Law, University of Gothenburg, Sweden

Nahar, B., \& Siriwardana, M. (2009). The Impact of trade liberalization on poverty in Bangladesh: A quantitative assessment. South Asian Economic Journal, 10(9), 325-369.

Pesaran, M. H., \& Shin, Y. (1999). An autoregressive distributed lag modeling approach to cointegration analysis. In Strom, S. (ed.), Econometrics and Economic Theory in the 20th Century: The Ragnar Frisch Centennial Symposium. Chapter 11. Cambridge: Cambridge University Press.

Pesaran, M.H., Y. Shin and R.J. Smith, (2001). Bounds testing approaches to the analysis of level relationships. Journal of Applied Econometrics, 16, 289-326.

Rahman M.M. (2008). The Foreign Trade of Bangladesh: Its Composition, Performance, Trend, and Policy. Journal of Bangladesh Studies, 9(2), 26-37.

Rahman, N. N., (2013). Policy Reforms and Trade Liberalization in Bangladesh. http:/ / www.unctad.info/upload/TAB/docs/TechCoopera tion/bangladesh_study.pdf 
Raihan S. and Khondker B.H. (2013). A Review of the Evolution of Trade Policies in Bangladesh. Chapter 1, Bangladesh country report: trade and employment / International Labour Organization, ILO Country Office for Bangladesh. - Dhaka: ILO.

Raihan, S. (2008). Trade Liberalization and Poverty in Bangladesh. In Emerging Trade Issues for Policymakers in Developing Countries in Asia and the Pacific, Bangkok: ESCAP

Siddiki, J.U. (2002). Trade and Financial Liberalisation and Endogenous Growth in Bangladesh. International Economic Journal, 16(3), 23-37.

The Government of Bangladesh (2002). Bangladesh Economic Review 2002, 2006 and 2014.
Trade Policy Review of Bangladesh (1992). World Trade Organization, Geneva.

Trade Policy Review of Bangladesh (2000). World Trade Organization, Geneva.

World Bank (2010). World Development Indicator and Global Development Finance, Washington, DC: World Bank

World Bank (2014). World Development Indicators, Washington, DC: World Bank

WTO (2000). Trade Policy Review: Bangladesh. Report by the WTO Secretariat, World Trade Organization, Geneva.

WTO (2012). Trade Policy Review for Bangladesh, mid-October. 


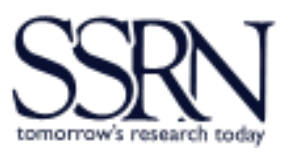

\section{SOCIAL SCIENCE RESEARCH NETWORK 2171 Monroe Avenue, Suite 203, Rochester, NY 14618, USA http://www.ssrn.com/en/}

AJTP Link: http://www.ssrn.com/link/American-Journal-Trade-Policy.html 